\title{
African leadership and the kind of reality of the spirit world
}

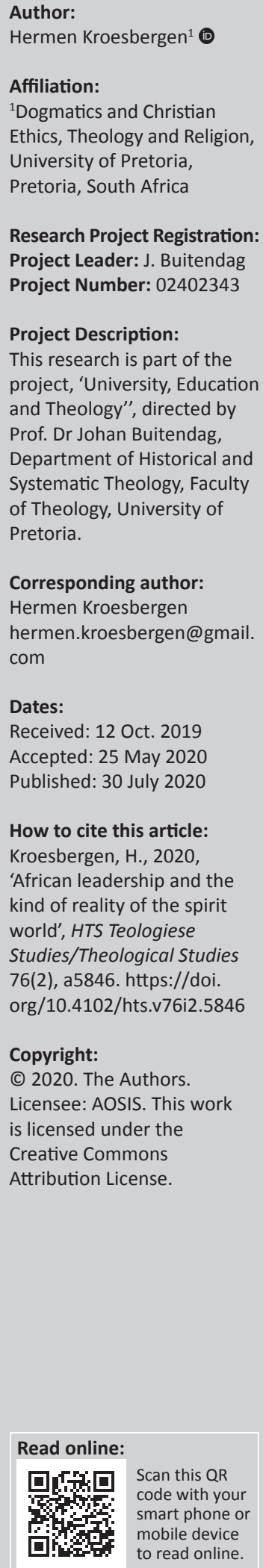

Leadership in Africa is inextricably connected to the spirit world. Leaders may be chosen through elections or other human processes, but ultimately, they are seen as appointed by God. Leaders may base their decisions upon science or intuition, but ultimately, they let themselves be inspired by revelations from the spiritual realm. Yet, what is meant by the spirit world in this respect? In this article, a new way is explored for investigating what references to the spirit world mean. Instead of discussing which theoretical concept applies to the kind of reality spirits have, or what analogy fits spirits, I demonstrate that we can discover what it means to speak of the spirit world by investigating what we already know about it before theoretical labels and comparisons. Such a Wittgensteinian approach in line with the re-emerging brand of ethnographically informed philosophy of religion enhances our understanding of what kind of reality the spirit world has. If you see leadership as being empowered by the spirit world, this is not a choice, option or interpretation, but you cannot see it any other way.

Contribution: This article contributes to a better understanding of the kind of reality that the spirit world has, in particular in an African context. The topic of leadership in Africa is used here to illustrate how this kind of reality is often misunderstood. A clear understanding of the kind of reality of the spirit world is indispensable for a proper investigation of Christianity in Africa and religion in general.

Keywords: Spirit world; Ludwig Wittgenstein; African leadership; Ethnographically informed philosophy; Reality.

\section{Introduction}

In 2018, after his own political party had failed, Zambian politician Miles Sampa returns to the ruling party. He wants to serve the President, for he now realises that leaders are appointed by God. Sampa (cited in Ncube 2018) explains:

If you disrespect any leader, God will bring you down. If you kneel down to any leader appointed by God, God will uplift you [...]. So I am coming to serve the President. (n.p.)

Earlier that year, the same President had initiated a Ministry of National Guidance and Religious Affairs, and the newly appointed Minister considers the President also to be 'a man of God, he hears God, he has been obedient to God to create the Ministry' (Kaunda 2018:236).

'Religion and politics have been linked throughout African history', Stephen Ellis and Gerrie ter Haar (1998:187) observe. In itself there is nothing special about this connection; in Europe or the United States, politicians use religion as well to gain popular support. There is something different in Africa, however. Ellis and Ter Haar (1998) continue:

In many cases [African politicians] also believe that access to the spiritual world is a vital resource in their constant struggle to secure advantage over their rivals in political in-fighting. (p. 188)

Religion or the spiritual world is more than a tool to mobilise people for African leaders; it is the resource for their power itself.

From the common African perspective, the spirit world, whether it is Christian, Muslim or traditional in nature, determines who will become a leader, and the spirit world inspires what this leader should do. In these two ways, the spirit world is even more important for African leaders than for European or American leaders. 
The current Zambian President Lungu has been hailed as a 'God ordained leader' (Kaunda 2018:229), and the same has been said about one of his predecessors, President Chiluba. A church leader described Chiluba as God-sent, anyone who disrespected him was disrespecting God who put him there, and whoever disagreed with him, disagreed with God (Njovu 2002:58).

The connection with the spirit world makes leaders untouchable and unaccountable. No human being or structure can replace them for no human being or structure placed them in that position in the first place. No human being or structure can criticise them for their decisions are based upon knowledge from beyond. Superficially, African leaders may obtain their powers through elections or bureaucratic systems, but on a deeper level, the spirit world appoints them, so it is said. Superficially, African leaders may make their decisions based upon scientific research or what the people want, but on a deeper level, their decisions are based upon revelations from the spirit world. Scholar of African Pentecostalism Ogbu Kalu (2008:199) speaks of a 'magical substratum that underpins the political culture' in Africa. And Ellis and Ter Haar (2004:8) emphasise that 'communication with the spirit world is a key concern of African politicians'.

The spirit world plays an ambiguous role in the reception of African worldviews. Early European visitors noticed that people in Africa often referred to the spirit world without having a clear belief system concerning it. They concluded that Africans did not have religion (see Kroesbergen 2019a). Nowadays, most people follow the renowned African theologian John Mbiti in holding that Africa is 'notoriously religious'. Mbiti (1990:195) bases his claim on the fact that for Africans nothing happens by chance, but everything has a mystical cause in the spirit world. The spirit world in Africa is not very defined, but it explains everything. Therefore, this spirit world is also of crucial importance to understand leadership in many African contexts. The twofold connection to the spirit world mentioned above is what makes an African conception of leadership stand out. Yet, what does it mean to speak of the spirit world, in particular in as far as it is seen as the foundation of and guidance throughout leadership?

Firstly, I will explain why I do not differentiate between Christian and a non-Christian spirit world nor between different kinds of spirits, and I will explain the method I will use to address the question about the kind of reality that the spirit world has. Secondly, I will discuss the attitude that belongs to believing that the spirit world underpins leadership. Thirdly, I will discuss the content of this belief and how it contrasts with more factual beliefs. In conclusion, I will reiterate that if you see leadership in this way, you cannot see leadership otherwise.

\section{Approach}

When Miles Sampa said that leaders are appointed by God, he was referring to the Bible ( $\mathrm{Rm} 13: 1)$. Connecting the spiritual realm to leadership is both Christian and traditionally African.
In this article, I will not differentiate between religions. Concerning leadership in Africa, the Christian God and the traditional spirit world fulfil the same function: appointing leaders and guiding them. Many Christians in Europe and the United States may have a different perspective; the Reformer Martin Luther, for example, already differentiated between two spheres, the kingdom of man and the kingdom of heaven. African theologian Samuel Waje Kunhiyop (2012:53-63) proposes to learn from the African traditional perspective on the spirit world, differentiating between many different kinds of spirits. However, so he (2012:53) says, 'Christians need to base their thinking about the spirit world on the Bible, rather than on traditions'. Yet, within the Bible different perspectives on the spirit world are left standing next to each other: in the synoptic Gospels, exorcism of evil spirits is very important, but in the Old Testament, John and Paul do not seem familiar with the practice. Therefore, I will not try to reconcile the African Christian perspective on the spirit world with the Euro-American one either.

Traditionally, the spirit world in Africa was ambiguous and very differentiated. This has changed. Already in the 1970s, Zambian Archbishop Milingo, hailed as 'one of Africa's leading demonologists' (Ellis \& Ter Haar 1998:198), did not differentiate between different kinds of spirits. Ter Haar (1992) comments:

It seems that modern Zambians increasingly consider that there is only one type of spirit possession, namely that caused by evil spirits, although it may be called by different names depending on which language one speaks or from what part of the country one originates. (p. 113)

Milingo called all of them mashave. Since the 1970s, local differentiations between spirits have evaporated even more. There is discussion over whether Milingo considered ancestor spirits to belong to the same category of evil spirits (Ter Haar 1992:141) - most people I have met in Zambia do so - but for this article, it is not very relevant whether ancestors belong to the good spirits or the bad spirits.

In the conception of leadership that I will be discussing in this article, leaders are appointed and guided by the Holy Spirit or good spirits, whereas there are evil spirits who try to dethrone or misguide them. This conception applies to Christian and non-Christian contexts in Africa, but as the experiences I will rely upon are from the predominantly Christian country Zambia, most examples will be placed in a Christian setting. My aim is merely to understand this conception; I will not venture to evaluate it in terms of truth, superstition or orthodoxy.

The question of what it means to speak of the spirit world can be approached in different ways. Many theoretical concepts, categories and schemas have been used, in various attempts to take references to the spirit world seriously. It is assumed that the kind of reality that spirits have for those who speak of spirits is a factual kind of reality. African philosopher Kwame Appiah (1992:116ff), for example, follows Robin 
Horton who placed African traditional thought in the same category as Western science; both are 'explanatory systems of belief' that share the problem of underdetermination. Both the discourse about the spirit world and scientific theories introduce theoretical concepts to explain, predict or control the world around us. More recently, renowned historian Yuval Harari expressed a similar approach to classifying spiritual language. He (2015:144) speaks of 'a third level of reality: the intersubjective level'. Spirits - like money, or nations, or quarks - are intersubjective entities who depend for their existence upon the communication between many humans. Both Appiah and Harari treat language about spirits as referring to hypothetical objects. These objects were supposedly introduced to explain parts of our reality that remain obscure as long as we speak in plain ordinary language. 'Explanatory systems' or 'intersubjective entities' are theoretical labels that are introduced to classify and understand what speaking of and believing in the spirit world comes to.

A related approach is to look for analogies. If spirits belong to 'explanatory systems of belief in a context of underdetermination', then spirits may be analogous to quarks or leptons (Veldsman 2000:165). Others have drawn comparisons between the reality of spirits and the reality of the 'invisible hand' that Adam Smith introduced in economics, or the concept of 'capital', 'like a spirit, capital is an abstraction, a concept, that may acquire material form' (Ellis \& Ter Haar 2004:115). Most of the proposed analogies are meant to account for the fact that even for someone who truly believes in spirits the spirits remain invisible. Although for this person spirits are some kind of objects, they are objects in a qualified and extended way. Many different analogies have been proposed, each, like all analogies, with their strengths and weaknesses.

A problem with both theoretical interpretations and analogies is that they often lead to a debate about labels and comparisons, rather than about what we wanted to understand in the first place, namely, what it means to speak of and believe in the spirit world.

Do people who believe in spirits, believe them to be real? Yes, but not in the sense that houses are real, and should we then still call it 'real'? Is it like quarks, but what are quarks exactly, and what is their reality status?

Elsewhere I have discussed the complexities of applying the concept of 'belief' to the context of religion in Africa (Kroesbergen 2019a). As will become clear when we discuss practical examples below, it remains necessary to distinguish between merely speaking of the spirit world and really believing in it. Yet, such distinctions are confused rather than clarified by theoretical discussions about what is 'real'. A discussion about what does and what does not deserve the label 'real' does not help us to understand what it means to speak of or believe in the spirit world. Therefore I propose a different approach in this article.
In response to the criticism that the philosophy of religion has focused too much on religious ideas, several directions of a more embodied investigation of religion have been proposed. One of these approaches is the re-emerging brand of ethnographically informed philosophy of religion in line with Wittgenstein (Burley 2016; Harrison 2018:4). Ethnography in this context does not refer to the classical quasi-objective descriptions of a particular tribe but to the form of ethnography that came in vogue during the 1960s, 'the self-reflective "fieldwork account"' (Clifford \& Marcus 1986:14). This reflects how Wittgenstein did philosophy. In this article, I wish to show that Wittgensteinian philosophy can offer a valuable contribution to the debate about the spirit world as well. Often scholars of religion assume that it is clear what it is to speak of and believe in the reality of spirits and miracles. Wittgensteinian philosophy of religion, however, takes a step back and first attempts to show which concept of reality is at work in what people say about religious concepts like the spirit world. What Mikel Burley (2014:86) says about God's reality applies to the reality of the spirit world as well, '[t]he Wittgensteinian is claiming [...] simply that we must look to language to see the sense of terms such as "God's reality"'. We need to investigate the kind of reality that the spirit world has. In this article, I will use my experiences in Zambia as an example.

As I (Kroesbergen 2014:190) have argued before, it is important to 'acknowledge both that our language is relative to the context in which we find ourselves, and that our language deals with reality' (see also Kroesbergen 2019b). This is a form of what could be dubbed 'ordinary realism' and it works by providing reminders of how language is used in everyday life. Instead of looking for the correct theoretical description, or the most fitting analogy, I wish to start at the other end: What do we know already about believing in the spirit world, before we start theorising about it?

\section{The attitude in believing in the spirit world}

The spirit world in Africa is not only connected to leadership but permeates every aspect of life. I am from the Netherlands, but for six years, I have been teaching at Justo Mwale University in Lusaka, Zambia. One of the most difficult topics I had to teach there was pastoral care when I had to stand in for a colleague. Throughout the course, the same pattern repeated itself; I thought the pastor should encourage his congregants to talk and have a conversation, whereas the students thought a powerful prayer by the pastor was both expected and more effective. If someone is possessed by evil spirits, so I was asked, or if someone is under attack from witchcraft, what good will it do to have a conversation? Is it not much easier and more efficient to simply pray the evil spirits away with a powerful prayer?

At first, I did not know what to do with such kind of comments. I was and still am not used to speaking of spirits or witchcraft. After a while, however, I decided to try to talk along, to use the language of my students to try to explain 
what I wanted to bring across. I started to say things such as, 'okay, maybe powerful prayers are more efficient to get rid of evil spirits, but would it not have a much longer-lasting effect if, instead of us as pastors solving our congregants' problems, we help them to solve their problems on their own? Through conversation, we may be able to give them the tools to ward off evil spirits for themselves in the future.'

This seemed to be accepted. I was glad to see that nobody appeared to question my way of speaking of spirits.

Now, this example is rather innocent, and after one term the lecturer practical theology returned, so I could retreat safely into systematic theology, ethics and philosophy again. Imagine, however, that I had continued teaching this course. That more and more practice would allow me to use the language of spirits and witchcraft in a way that was both acceptable to the students and enabled me to say what I wanted to say. Imagine I speak like this about spirits and witchcraft so often, that I start to use this language in my personal life as well. I speak of evil spirits when I encounter problems, I tell people I am bewitched when I fall ill. I start to drink the teas that are traditionally prescribed for healing and wear amulets to make sure I will not fall ill as easily again. Does this mean that I have started to believe in the spirit world? It could. But does it necessarily mean that I now believe in the spirit world? I do not think so. In fact, there might still be an enormous gap between me who speaks of the spirit world and someone who believes in the spirit world.

If I had become comfortable with speaking of spirits during class, I would have learned to use the language of spirits and witchcraft - it would now even come naturally to me. I would have accustomed myself to the practices surrounding this language, yet it may be that for me it is still no more than 'a way of speaking about and dealing with bad fortune'. It still does not need to be 'believing in the spirit world'. I may have learned to say that God appointed the president, but I would still think that it was actually the people in the elections and a bit of luck or corruption that made him president. Of course, it could change into really believing in the spirit world, but, in that case, what kind of change would that be?

There are no definitive answers as to whether someone truly believes in the spirit world. Someone may even at a later stage come to realise, 'I thought I believed in the spirit world, but now I see that before I never really believed in it' or, 'I thought I did not believe in the spirit world and that I was merely accommodating my students, but now I see that it has always been more real to me than I was aware of'.

And then again, one may at some point come to see these realisations themselves as misguided, and so on. Statements about really believing are themselves part of a perspective, they are not referring to plain facts that could be established in a laboratory setting, but they belong to a particular way of seeing things.
To discover whether someone actually believes in the spirit world, we look at their life, to the attitude that someone takes to their life. We may collect evidence to say 'yes' or 'no', but the evidence will never be conclusive. The evidence from someone's life can always be interpreted differently as well. To say that someone truly believes in the spirit world requires the observer to take a personal stand. Yet, we can make some neutral observations about what it is to believe in the spirit world as well, like for example, believing in spirits is not something positive to aspire to or something negative, but it is simply recognising that there are spirits out there and that we have to deal with them. One is, of course, aware of elections and bureaucratic systems, but ultimately the spirit world appoints the next president. One is familiar with the many reasons and considerations for a leader to make a particular decision, but ultimately, the leader's task is to discern the messages from the spirit world. People do not want to believe in the spirit world, they do not assume to benefit from believing in spirits, they are simply acknowledging their reality. Whether it is good or bad does not matter, it is a part of one's attitude to life. It is important to keep this in mind when we speak of how to identify whether someone truly believes in the spirit world: it is not a goal to reach, it is merely something someone finds themselves doing or not.

The shift from merely speaking of spirits to actually believing in spirits may happen in many different ways. It may happen suddenly, either triggered by a dramatic event, or for no reason in particular, 'now I know it is real. I always thought I was merely accommodating my students, but now I see that spirits really exist'. Or it may happen gradually, without me even noticing. Maybe after some years, a friend from the Netherlands notices, 'you really do believe in spirits, don't you?' - and, upon reflection, I may have to admit 'Yes, I actually do'.

I would say that in all of these cases, a fitting description of the change would be that 'My eyes have been opened'. That is to say the change is not something in reality, but something in me observing reality. Light dawns over a world. Although the change happened in me, the spirits do not depend upon me or anybody for their existence - they are out there in reality, whether someone notices it or not. Once I start to believe in spirits, I will see that spirits have been real all along. Before the opening of my eyes, I did not see spirits, but looking back, retroactively, I now notice that they have been there and played a role in the past as well. Spirits do not exist because a group of people have agreed that they do, but to believe in the spirit world is to know that, whether or not anyone acknowledges it, spirits are out there, causing events that nothing else can cause. Something similar goes for realising that spirits do not exist after all; in such a case, spirits do not cease to exist, but I would say that spirits have never been real at all. The reality or non-reality of spirits does not depend upon anyone's acknowledgement of these facts.

There is a choice involved in learning to speak of the spirit world. There is a choice involved in deciding to phrase one's descriptions of what happens in terms of spirits. However, 
there is not a choice involved in believing in the spirit world. A person finds themselves believing in the spirit world or not believing in the spirit world - there is nothing this person can do about it. Whilst I am fully aware that not everybody believes in the spirit world, and I am fully aware that I used to not believe in the spirit world, once I do, I cannot do otherwise. Spirits are there, it has nothing to do with me or my choice. I could try to deny it - indeed it has often been noticed that people in Africa deny emphatically that spirits exist in order to reduce the influence of spirits on their lives (see Kroesbergen 2019a:8) - but if I find myself believing in them does not matter, deep down I will simply know they are there. It is not someone's choice to believe in the spirit world, but for one who believes in the spirit world, the spirit world is simply part of the reality one has to deal with.

Coming from the West, one may be tempted to assume that spirits must be something outside reality, but for someone living in a world with spirits, they are simply what one sees when one opens their eyes. As Harari (2015) observes:

Few people put their faith in supernatural powers. For those who believe in demons, spirits and fairies, these beings are not supernatural. They are an integral part of nature, just like porcupines, scorpions and germs. (p. 211)

Just like we do not choose to see porcupines or germs, people who speak of the spirit world do not make an active choice they simply report what they observe.

One's attitude towards the world and leadership changes, but not in the sense that one chooses one's attitude. When one begins to believe in the spirit world, one's eyes have been opened (that is: passively) to reality (that is: to something out there irrespective of oneself or one's acknowledgement). You see that the leader is appointed by God; you see that proper leadership decisions are based upon revelation. It is a matter of observation, not of choice. Yet, what is it that one sees, what is the content of believing in the spirit world?

\section{The content of believing in the spirit world}

To believe in spirits is to see things that people who do not believe in spirits do not see. However, what someone sees is generally not the spirits themselves. Spirits are invisible, that is an important part of what makes them spirits. Someone who believes in the spirit world in most respects sees the same actual reality, but they see spirits being active in it. They see the same things and the same events, but, according to their experience at least, they see this reality more truly. The content of believing in the spirit world has to do with what is beyond ordinary reality by definition. This is the first point I wish to make in this section. Secondly, beliefs about the spirit world can oddly enough not be mistaken. And, thirdly, the content of believing in the spirit world cannot be reduced to a substratum of plain facts.

Firstly, spirits are generally invoked when ordinary explanations are not available. When I learned to speak of the spirit world in daily life in Zambia, I learned to do so in those cases where I did not know why something happened. These were cases where I would have said previously that something was bad luck, a coincidence or, what Harari (2015:235) says is the motto of modernity, 'shit happens'. Spirits are seen to act where there are no ordinary causes available.

In politics this is no different. More people vote for person A than for person $B$, why? Most often, many reasons can be given, but these reasons are hardly ever conclusive. Why is A more likeable than B? Charisma, people may say in the United States. Why does one ideology appeal more to the people than the other? Zeitgeist, people may say in Europe. Yet, referring to 'charisma' or 'Zeitgeist' is in most ways no more than admitting that we do not know. Person A is likeable because they are likeable. Ideology $X$ appeals because it appeals. These are the cases in which people in Africa speak of the spirit world. Once I truly believe in the spirit world, I see it as really the work of spirits, but these spirits will still be seen as active in those cases where ordinary explanations are not available. Even once I truly believe in spirits, even if talk of spirits for me no longer is a replacement for speaking of charisma or Zeitgeist and I really take spirits to be involved in what is happening to me, then spirits would still be active in this kind of rest category of what cannot be explained in an ordinary way. Both words like charisma and Zeitgeist and words referring to the spirit world are what I (Kroesbergen 2019a:12) called elsewhere 'left-over containers with respect to explanations'. To speak of these things is a way (Kroesbergen 2019a):

$[T]$ o deal with what is not clear and certain. It is a response to the insecurity of the world. It is a normal part of life, but the part that remains insecure. (p. 12)

Whether one truly believes or not, speaking of spirits would still be speaking of the beyond, speaking of that what does not fit ordinary explanations.

If it is clear that John did something, someone who believes in spirits is not going to argue that a spirit did it instead. At the most, they might say that a spirit inspired John to do it or even guided John's hand. A spirit may be involved, but then as the cause of the cause. It is not because spirits are so extremely mysterious that science has so far never discovered them. It is part of how people speak of spirits that they ascribe to them what cannot be discovered by either common sense or scientific methods. It is part of the definition of spirits - both for people who do believe in spirits and those who do not.

Advice from spirits is asked in cases where the uncertainty that someone is facing cannot be solved in a calculating kind of way. Investigating the anthropology of magic, Susan Greenwood (2009:112) observes that it is used to address questions like 'Should I stay in my present relationship or should I go travelling?' 'Should I have another baby?' 'Should we stay together?' and 'Should I accept this job offer or not?' 'Should I tell the truth or better just leave it?' These questions 
for which straightforward determining mechanisms do not work are the kind of questions that are addressed to the spirit world. Similarly, concerning leadership, scientific and political advisors may tell a leader why they should do A or $\mathrm{B}$, but ultimately in most cases, a decision needs to be made that cannot be fully justified. Several anthropologists have noted the similarity in subject matter for a spin-doctor and a witch-doctor in this respect (see for example Ellis \& Ter Haar 2004:74). In Europe and the United States, people may say that the leader uses their political intuition in making such choices, in Africa one speaks of the spirit world. To speak of spirits is to speak of that which is beyond ordinary reasons or explanations.

In many parts of Africa, leadership belongs to the special category of professions that are supposed to need spiritual assistance. Johanneke Kroesbergen-Kamps (forthcoming) describes, for example, that in Zambia:

$[B]$ ecoming a chief is not simply a hereditary matter. Although most chieftaincies are linked to a specific clan or lineage, birth is not the main criterion. There is usually a group of candidates for the succession of a chief. To be elected, some individual merit or support from invisible forces is needed. (n.p.)

Spirits or invisible forces are referred to when something is not completely determined. Who is the leader and how much power the leader possesses is ultimately explained by the machinations of the spirit world, that is, described from another perspective: it is ultimately unexplainable.

For Nigeria, Nimi Wariboko (2014) uses this to explain the often discussed practices of corruption in Africa:

Time is always running out. [...] There is not enough time for politicians to steal before the next election because their invisible godfathers (politicians, native doctors, and babalawos) behind the throne may not allow them back into office. (p. 287)

Leaders represent the spirit world, but everyone is aware that this implies that leaders do not control their destiny, 'No one has a mastery of her world in this highly uncertain world' (Wariboko 2014:287).

Many things cannot be discovered by common sense or scientific methods. We could use phrases like charisma or intuition for those, but, once I believe in the spirit world, I know that the real cause of these events is spiritual. To believe in the spirit world means to be aware that nothing happens without a reason. People who do not believe in the spirit world may think of many occurrences as luck or bad luck, people who do not believe in the spirit world may learn to use the words 'spirits' or 'God' to accommodate their students, but that means they are still blind to an aspect of reality, to how nothing is a coincidence. To believe in the spirit world is to be aware of this aspect of reality itself.

Spirits belong to the beyond, and strangely enough, what people say about spirits cannot be mistaken. We may want to ask whether someone is right to believe in spirits. Were there really spirits behind person A winning the elections or leader B making that decision? Yet, we know that such a question will not do. Even if someone engages in serious scientific research and states in their final report, 'spirits indeed caused person A to win the elections', we would not take that as a research finding. Rather, we would take that as a confession that the scientist believes in spirits. If they did not believe in spirits before their research, we would take it as an account of their conversion, of how their eyes were opened. Vice versa, the same goes for 'It is not true that spirits caused person A to win the elections'. This would not prove anything to me if I believe in spirits, it would merely tell me about the personal beliefs of this particular scientist. If the scientist did believe in spirits before their research, as a believer I would say that the research has confused them, that they are no longer able to see something that is actually there.

If I say that I believe spirits caused person A to win the elections, I may be lying if I do not really believe that spirits exist. But in an important way, I cannot be mistaken about it. At some point, I may come to realise that there are no spirits after all. That, however, would again be more a case of my eyes being opened, rather than a case of discovering a mistake. From my new perspective - the one without spirits - I consider it to be wrong to ascribe the election result to spirits, but that is more like looking at what happened from a different angle.

If a person believes in the spirit world, they cannot say that, of course, not believing in the spirit world would be okay as well, but they just happen to believe in the spirit world. Not believing is not all right also because spirits happen to be a part of reality. Vice versa, the same goes for those who do not believe in the spirit world. Yet, neither of them is mistaken or can be mistaken. The concept of mistake does not apply here. One finds oneself believing or not believing, one cannot do otherwise than one does. To believe in the spirit world (or not) is the only thing that one can do. Nothing else is possible. One cannot be mistaken in believing in the spirit world, or in not believing in the spirit world for that matter. It is what this person believes, that is all. This obviously does not mean that we are infallible or that we must be right in what we believe, but the question of whether we are mistaken makes no sense here. If at a later stage in our lives we find that our beliefs regarding the spirit world have changed, we did not discover a mistake, but we now simply believe something else. If a person believes in the spirit world, not believing in it may be quite unimaginable, even if this person did not always believe, and vice versa, but neither is right nor is a mistake. It is what it is, it is what we personally cannot but see in reality.

For one who does not believe in spirits, it makes no sense to do experiments to prove that spirits do not exist, for they know that they do not beforehand. They could not even imagine otherwise. For one who does believe in spirits, experiments would not make much sense either; they know they are there, whatever the outcome of any kind of research. Both sides may use what looks like experiments to try to convince the other, but they know that their own belief or 
disbelief does not rest upon the outcome of such experiments, and they know that experiments in themselves will never convince the other. At best they may provide the occasion for the other to have their eyes opened to what is obviously the case or not the case. This would be a case of conversion, not of being convinced by reason.

Firstly, spirits belong to the beyond; secondly, beliefs about spirits cannot be mistaken and the third point, I wish to make here is that the content of believing in the spirit world cannot be reduced to some substratum of plain, objective facts. If I start to believe in the spirit world, I will be aware that there are people who do not believe in spirits - in fact, I will remember that I myself once did not believe in spirits. I will say that these other people are missing something, that they are not seeing something that is really out there in the world. Probably I would wish to open their eyes as well like my eyes have been opened, but I know that since it is a matter of seeing, showing them some new plain simple facts alone will not do the trick. Facts may trigger someone to open their eyes, but facts in themselves cannot force someone to see, to truly see. For everything, every fact or event could be either explained differently or left as something unexplainable by those who do not see. For me as a believer in the spirit world, it would be obvious that there have been spirits at work, but I would remember that the old me, before my eyes were opened, would not or not necessarily have seen spirits in such an event. Once a person starts to believe in the spirit world everything around this person has changed, and yet they are aware that in another sense nothing has changed.

By seeing spirits I would now know what is really going on, but there are no plain facts of the matter that could be proven in a laboratory setting that in themselves would show that there must be spirits. Once I believe in spirits, when asked why something happened, why now and why to me, I will consider 'Spirits did it' a much more likely and convincing answer than 'I don't know', but I will be aware that some people stubbornly prefer to hold on to 'I don't know' rather than to admit that there is a spirit world. I will remember I was once one of those people myself.

As long as I merely use the language of spirits and the practices that are connected to it, speaking of spirits is for me something that could be described differently as well. I used to say 'charisma' or 'intuition' for example, now I say 'spirits', but it refers for me to the same thing or event in reality. I used to say 'accident', now I say 'witchcraft', but what I take to have happened in reality is no different. Once I start to really believe in spirits, however, this is what changes. Now I see that it was really evil spirits who caused it. 'Bad luck' may have been a fairly adequate description back when my eyes had not yet been opened, but now I see what is really going on. 'Spirits' is no longer a description of what could just as well have been described otherwise, but now I see that spirits are really behind all that is happening. The spirits are out there in reality, they are there, for everyone to see, although I am aware that not everyone is actually seeing them. I now consider those who do not see them to be blind to a particular aspect of reality. Only the description of events that involves spirits truly describes what is going on. Any description that leaves out spirits misses an aspect of what is really happening.

For someone who believes, speaking of spirits is no longer an interpretation of reality, because an interpretation is always an interpretation of something: on the one hand, there are the plain facts of the matter; on the other hand, there is the interpretation of these facts. For someone who believes in the spirit world, there are no plain facts of the matter other than those that do already involve spirits. Therefore, for someone who believes in the spirit world, there is nothing that needs to be interpreted: someone just needs to open their eyes and see. Of course, leaders are ultimately appointed by God; elections and bureaucratic systems cannot explain everything. Of course, decisions by leaders should be based upon revelations from the invisible world; the arguments of their advisors will never be completely conclusive.

At the time, when I was still merely using the language of spirits, I could distinguish between, on the one hand, something that happened for which there is no common sense or scientific explanation, and, on the other hand, me speaking of this something as 'spiritual'. As soon as I believe in the spirit world, however, this distinction no longer applies to me; it is part of the plain facts that spirits are behind this or that. People who force the description upon me that I am interpreting something is merely showing that they do not believe in the spirit world. They think they are looking at the plain facts and observing that I add some further descriptions to those facts, but in reality, so I would say, they are not seeing what is really going on; it is part of the facts that spirits are causing this and that. What we take to be the raw or plain facts of the matter depends upon whether we believe in spirits or not. As a believer in the spirit world, one would say that others are blind to a certain, important aspect of reality.

\section{Conclusion}

To believe in the spirit world is not something to be commended or not, it is simply what one finds oneself doing whether one wants to or not. Whether we believe in the spirit world or not shows itself in the role that what we say about the spirit world plays in our lives, but there are no definitive answers to the question of whether one believes. To say that one believes or not is itself often a personal matter. To believe in the spirit world is not to apply some interpretation to the raw material world around us, but it is to discover that one's eyes have been opened to an aspect of reality itself. Someone who comes to believe in the spirit world now sees what is really going on in what used to be the unexplainable beyond of questions like 'Why is candidate A more likeable than candidate B? Why does everyone now support policy $X$ and opposes policy Y?' By definition, spirits are not entities to be discovered scientifically; they are not objects we can be mistaken about or not, to believe in the spirit world or not is simply something we cannot do otherwise. 
To return to the theoretical concepts that have been applied to believing in the spirit world, if someone wants to say that believing in spirits means believing in particular entities out there in the world, one needs to remember that spirits are in many ways beyond objects and entities by definition. If someone wants to say that believing in the spirit world is believing in particular matters of fact or something ontologically real, one needs to keep in mind that in the case of spirits there are no neutral plain facts of the matter that await interpretation, but both sides - belief and non-belief already imply a personal perspective.

With regard to the analogies that have been used, a major difference between quarks or the invisible hand in economics and spirits is that spirits are not hypotheses; about spirits one cannot be mistaken. In practice, hypothetical scientific entities may be rendered immune to falsification as well, but scientifically this ought to be considered as a weakness or problem. Spirits are not like money in the sense that spirits are seen to exist in reality independent of human conventions; someone's eyes are being opened when they come to see spirits, one's eyes are not opened in that way when one starts using money. The analogy with beauty is quite promising, in the sense that beauty and spirits both are not traceable in a laboratory setting, yet they are experienced as being out there, in the world, open for anyone with eyes to see, although we are aware that some may be blind to this aspect of reality.

Discussions about what does and what does not deserve the label 'real', however, do not help us to understand what it means to believe in the spirit world. It may be tempting to some to try to build a system within which both Western and African ideas about reality and spirits are allocated a place (see, e.g. Ter Haar 2009; Turner 1992); however, to adopt such a system would not be to do justice to African belief systems, but it would be to introduce yet one more belief system. Nor should we try to build a neat system that allocates God, the Holy Spirit, angels, mashave, ancestors, demons and so on, each their own specific place (Heiser 2015; Kunhiyop 2012:5363). To believe in this system would reflect yet one more personal perspective. Instead of building abstract systems, we ought to look at what we know before we debate theoretical labels or comparisons. This answers already what we want to know when we try to understand what it means to believe in the spirit world. Therefore, instead of discussing theoretical concepts and analogies, I have used a different approach in this article.

Leadership in Africa is inextricably connected to the spirit world. This does not imply that Africans give another interpretation to the same plain facts as Westerners do, or that we have to assume that they are mistaken. If we look at the role that the belief in the spirit world plays in people's lives, we see that for them it is simply a part of life for which their eyes have been opened. Referring to the spirit world to explain why someone is a leader or which decision they should make is not presenting a theory about mysterious forces out there, but it is to acknowledge, from within a particular personal perspective, how leadership and power belong to the beyond. This is what it means to both speak of and believe in the spirit world, this is the kind of reality the spirit world has.

\section{Acknowledgements Competing interests}

The author declares that he has no financial or personal relationships that may have inappropriately influenced him in writing this article.

\section{Author's contributions}

H.K. is the sole author of this research article.

\section{Ethical considerations}

This article followed all ethical standards for research without direct contact with human or animal subjects.

\section{Funding information}

This research was funded by the Senior Postdoctoral Fellowship provided by the University of Pretoria.

\section{Data availability statement}

Data sharing is not applicable to this article as no new data were created or analysed in this study.

\section{Disclaimer}

The views and opinions expressed in this article are those of the author and do not necessarily reflect official policy or position of any affiliated agency of the author.

\section{References}

Appiah, K.A., 1992, In my father's house: Africa in the philosophy of culture, Oxford University Press, Oxford.

Burley, M., 2014, 'Wittgenstein, religion, and the rejection of metaphysics', in Y. Gustafsson, C. Kronqvist \& H. Nykänen (eds.), Ethics and the philosophy of culture: Wittgensteinian approaches, pp. 74-91, Cambridge Scholars Publishing, Cambridge.

Burley, M., 2016, Rebirth and the stream of life: A philosophical study of reincarnation, karma and ethics, Bloomsbury, New York, NY.

Clifford, J. \& Marcus, G.E. (eds.), 1986, Writing culture: The poetics and politics of ethnography, University of California Press, Berkeley, CA.

Ellis, S. \& Ter Haar, G., 1998, 'Religion and politics in Sub-Saharan Africa', The Journal of Modern African Studies 36, 175-201. https://doi.org/10.1017/S0022278X9800278X

Ellis, S. \& Ter Haar, G., 2004, Worlds of power: Religious thought and political practice in Africa, Oxford University Press, New York, NY.

Greenwood, S., 2009, The anthropology of magic, Berg, Oxford.

Harari, Y.N., 2015, Homo deus: A brief history of tomorrow, Harvill Secker, London.

Harrison, V.S., 2018, 'Global philosophy of religions for a pluralistic world', Keynote paper presented at the ESPR Conference, Prague.

Heiser, M.S., 2015, The unseen realm: Recovering the supernatural worldview of the bible, Lexham Press, Bellingham, WA.

Kalu, O., 2008, African pentecostalism: An introduction, Oxford University Press, Oxford.

Kaunda, C.J., 2018, 'Christianising Edgar Chagwa Lungu: The Christian nation, social media presidential photography and 2016 election campaign', Stellenbosch
Theological Journal 4(1), 215-245. https://doi.org/10.17570/stj.2018.v4n1.a11

Kroesbergen, H., 2014, 'Beyond realism and non-realism. Religious language-games and reality', Nederduitse Gereformeerde Teologiese Tydskrif 55(1), 189-204. https://doi.org/10.5952/55-1-2-521

Kroesbergen, H., 2019a, 'Religion without belief and community in Africa', Religions 10(4), Art. \#292, 1-20. https://doi.org/10.3390/rel10040292

Kroesbergen, H., 2019b, The language of faith in southern Africa: Spirit world, power, community, Holism, AOSIS, Cape Town. 
Kroesbergen-Kamps, J., [forthcoming], 'The usual suspects: Accusations of Satanism against politicians in Zambia', in C.J. Kaunda \& M. Hinfelaar (eds.), Competing for Caesar: Religion and politics in post-colonial Zambia, 1517 Media, Lanham.

Kunhiyop, S.W., 2012, African Christian theology, HippoBooks, Nairobi.

Mbiti, J., 1990, African religions and philosophy, 2nd edn., Heinemann, Oxford.

Ncube, S., 2018, 'I was impatient, immature, but God transformed me - Miles', NewsDiggers!, 06 July 2018, viewed 17 April 2020, from https://diggers.news/ local/2018/07/06/i-was-impatient-immature-but-god-has-transformed-me-miles/.

Njovu, D., 2002, 'The religious implications of the declaration of Zambia as a Christian state', Master's thesis, UNISA.
Ter Haar, G., 1992, Spirit of Africa: The healing ministry of Archbishop Milingo of Zambia, Hurst \& Company, London.

Ter Haar, G., 2009, How God became African: African spirituality and Western secular thought, University of Pennsylvania Press, Philadelphia, PA.

Turner, E., 1992, Experiencing ritual: A new interpretation of African healing, University of Pennsylvania Press, Philadelphia, PA.

Veldsman, D.P., 2000, 'Imagine substituting leptons and quarks for gods and spirits', Skrif en Kerk 21(1), 156-171. https://doi.org/10.4102/ve.v21i1.1188

Wariboko, N., 2014, Nigerian Pentecostalism, University of Rochester Press, Rochester, NY. 